\title{
Risk Factors for COVID-19 Infection in Rural Areas: A Cross-Sectional Study in Tegal District
}

\author{
Siti Putri Nur Kholifah'), Mahalul Azam', Muhamad Zakki Saefurrohim²) \\ 1)Public Health Science Department, Faculty of Sport Science, Universitas Negeri Semarang \\ ${ }^{2)}$ Masters Program in Public Health, Post Graduate Program, Universitas Negeri Semarang
}

\section{ABSTRACT}

Background: Although the COVID-19 outbreak initially occurred in urban residents, it eventually reached rural and remote communities. There have not been many studies of risk factors for COVID-19 infection in people in rural areas. This study aimed to determine the factors associated with the incidence of COVID-19 infection in rural areas, Tegal Regency.

Subjects dan Method: This was a cross-sectional study, conducted on 114 patients who visited the health center from 1 June to 30 July 2020 (time restrictions on social activities). The dependent variable was the incidence of Covid-19 infection. The independent variables were age, gender, signs, and symptoms (diarrhea, headache, conjunctivitis, anosmia, and skin rash), comorbidities, history of hospitalization, smoking status, travel history outside the city, and close contacts status. The data were analyzed using the chi-square test and logistic regression test.

Results: There was a relationship between variable gender $(\mathrm{OR}=8.21 ; 95 \% \mathrm{CI}=2.33$ to $28.9 ; \mathrm{p}=$ o.001), signs and symptoms $(\mathrm{OR}=6.16 ; 95 \% \mathrm{CI}=1.74$ to $21.85 ; \mathrm{p}=0.005)$, comorbid ( $\mathrm{OR}=11.75 ; 95 \%$ $\mathrm{CI}=2.83$ to $48.83 ; \mathrm{p}=0.001)$, close contact $(\mathrm{OR}=13.91 ; 95 \% \mathrm{CI}=3.45$ to $56.04 ; \mathrm{p}<0.001)$, and COVID-19 infection in rural areas.

Conclusion: Age, gender, signs and symptoms, comorbidities, smoking, and close contacts can increase the incidence of COVID-19 infection in rural areas.

Keywords: risk factors, COVID-19, rural area, cross sectional

\section{Correspondence:}

Muhamad Zakki Saefurrohim. Department Public Health, Faculty of Sport Science, Universitas Negeri Semarang, Semarang, Central Java, 50229, Indonesia. saefurrohim@students.unnes.ac.id. Mobile: 087710112314.

\section{Cite this as:}

Kholifah SPN, Azam M, Saefurrohim MZ (2021). Risk Factors for COVID-19 Infection in Rural Areas: A Cross Sectional Study in Kabupaten Tegal. J Epidemiol Public Health. 06(03): 372-380. https://doi.org/10.26911/jepublichealth.2021.06.03.11.

cc) (7) (2) Journal of Epidemiology and Public Health is licensed under a Creative Commons Attribution-NonCommercial-ShareAlike 4.0 International License.

\section{BACKGROUND}

The global COVID-19 pandemic was first announced on 11 March 2020, indicating that this virus has infected large populations in various countries. As of 25 March 2020, it has infected 175 countries with a transmission rate of 425,493 cases (WHO, 2020). COVID-19 was first reported in Indonesia on 2 March 2020 with two cases. Data on 31 March 2020 showed that there were 1,528 confirmed cases and 136 deaths. The COVID-19 mortality rate in Indonesia is 8.9\% and is the highest in Southeast Asia (Hastuti and Djanah, 2020).

Data from 22 March 2021 shows that COVID-19 cases in Central Java Province are ranked 13th in Indonesia (Kementerian Kesehatan RI, 2021). As of 23 March 2021, 169,097 positive confirmed cases with a death toll of 10,593 people spread across 35 
regencies/cities. For the distribution of COVID-19 cases in Central Java, it is recorded that Tegal Regency ranks 13th with 1,406 cases and 115 deaths (Dinas Kesehatan Provinsi Jawa Tengah, 2021).

Data on 18 December 2020 shows that the incidence of COVID-19 cases at the Slawi Health Center was ranked first in the work area of the Tegal District Health Office, which was 373 cases. Based on 3 April 2021, the percentage of the positive COVID-19 positivity rate in Tegal Regency is $16.19 \%$. The ratio is three times greater than the minimum positivity rate threshold set by the World Health Organization (WHO) standards, 5\% (Tegal District Health Office, 2020).

Transmission is by close contact and droplets, not by airborne transmission. People who are at risk of infection are those who are in close contact with people who are positive for COVID-19. Preventive action is the key to implementation in health and community services. The prevention step in the community is to maintain hand hygiene using hand sanitizer if the hands do not look dirty. Wash your hands with soap if your hands are visibly dirty. Avoid touching eyes, nose and mouth. And apply coughing or sneezing etiquette by covering the nose and mouth with the inside of the upper arm. Wear a mask and maintain a distance (at least 1 meter) from other people.

Conduct disease risk communication and community empowerment to increase knowledge (Kerbage et al., 2021; Liu et al., 2020; Ranscombe, 2020). Comorbid hypertension and diabetes mellitus, male gender, and active smokers are risk factors for COVID-19 (Mueller et al., 2021; Ranscombe, 2020; Zhonghua, 2020). This study aimed to determine the relationship between age, gender, signs and symptoms, comorbidities, history of hospitalization, smoking, travel history, and close contact with the incidence of COVID-19 infection in the work area of the Slawi Health Center.

\section{SUBJECTS AND METHOD}

\section{Study Design}

This was a cross-sectional study, conducted on 114 patients who visited the health center in Kabupaten Tegal from 1 June to 30 July 2020

\section{Population and Sample}

The population of this study were Patients who visit the community health center are given consent to become respondents until the minimum research sample is met. The case group is patients confirmed positive for COVID-19 based on PCR results, while the control group is confirmed negative based on PCR results. The sample size is set at 114 respondents with purposive sampling technique.

\section{Study Variables}

The dependent variable was the incidence of COVID-19 infection. The independent variables were age, gender, signs, and symptoms (diarrhea, headache, conjunctivitis, anosmia, and skin rash), comorbidities, history of hospitalization, smoking, travel history, and close contacts.

\section{Definition Operational of Variables}

The incidence of COVID-19 infectin are patients who carry out RT-PCR or Rapid Test laboratory examinations, which are recorded in the medical records of the Slawi Health Center from January to March 2021. Age is the age of the respondent when confirmed positive for Covid-19, which is calculated based on the year of birth. And then, gender is the respondent's gender. Signs and symptoms are respondents experienced at least three of the eleven signs and symptoms of Covid-19: (fever $38^{\circ} \mathrm{C}$, dry cough/phlegm, runny nose, sore throat, shortness of breath, headache, malaise, muscle pain, nausea or vomiting, abdo- 
minal pain, and diarrhea) when suffering from a Covid-19 infection. History of hospitalization are respondents were asked whether they had a history of hospitalization in the last 14 days before being tested positive for Covid-19. Comorbidities are respondents have a history of at least one of nine comorbidities (pregnancy, hypertension, diabetes mellitus, cardiovascular disease, cancer, HIV/AIDS, chronic kidney failure, chronic liver failure, and COPD) before being tested positive for Covid-19. Smoking status are respondents were asked whether they had a history of smoking before suffering from a Covid-19 infection.

Travel history outside the city are respondents were asked whether they had a history of traveling abroad or local transmission areas within the last 14 days before being tested positive for Covid-19. The local transmission area points for Covid-19 cases are based on geographic nodes at the district/ city level. Close contact status are respondents were asked whether they had a history of close contact with a confirmed/ suspected/probable Covid-19 case within the last 14 days before being declared positive for Covid-19.

\section{Study Instruments}

Data were collected using a structured questionnaire from the published literature and made some modifications to the instrument to contextualize it with diverse population situations. Patients who visit the community health center are given consent to become respondents until the minimum research sample is met.

\section{Data analysis}

Data is presented in frequency and percentage based on traffic accident experience. The chi-square test was conducted to analyze the relationship between risk factors and the incidence of COVID-19 infection in rural areas. $\mathrm{p}<0.05$ was con- sidered statistically significant. Risk factors with $\mathrm{p}$ value lower than $\mathbf{0 . 2 5}$ were included in the backward stepwise logistic regression analysis method (likelihood ratio). All statistical analyzes were performed using SPSS software version 22.0 (IBM Corp., USA).

\section{Research Ethics}

Research ethical issues including informed consent, anonymity, and confidentiality, were addressed carefully during the study process. The ethics committee has approved the research procedure with the number o81/KEPK/EC/2021.

\section{RESULTS}

\section{Sample Characteristics}

The majority of respondents in this study were aged <6o years (72.8\%), male (60.5\%), had signs and symptoms of COVID-19 (50.9\%), without a history of comorbidities $(56,1 \%)$, without a history of hospitalization (91.2\%), does not smoke (72.8\%), has no record of travel to infected areas (57.0\%), and has a history of close contact $(78,9 \%)$ (Table 1$)$.

\section{Bivariate Analysis}

Respondents in the age category 60 years who were confirmed positive for COVID19 were $90.3 \%$, while the age category $<60$ years who were confirmed positive for COVID-19 was $67.5 \%$. From the analysis results obtained there was correlation between age and risk of being infected with COVID-19 (PR=4.5O; 95\% CI= 1.26 to $16.12 ; \mathrm{p}=0.026)$ indicating that people aged 60 years have a 4.50 times greater risk of being infected with COVID-19 compared to people aged $<60$ years. (Table 2). 
Table 1. Respondent Characteristics

\begin{tabular}{lcc}
\hline \multicolumn{1}{c}{ Variables } & Frequency & Percentage \\
\hline Age & 31 & \\
$\geq 60$ years old & 83 & 27.2 \\
< 6o years old & & 72.8 \\
Gender & 69 & 60.5 \\
Male & 45 & 39.5 \\
Female & & \\
Signs and Symptoms of & & \\
Covid-19 & 58 & 50.9 \\
Yes & 56 & 49.1 \\
No & & \\
Comorbid & 50 & 43.9 \\
Yes & 64 & 56.1 \\
No & & \\
History of Hospitalization & 10 & 8.8 \\
Yes & 104 & 91.2 \\
No & & \\
Smoking Behavior & 31 & 27.2 \\
Yes & 83 & 72.8 \\
No & & \\
History of Travel to & & \\
Affected Areas & 49 & 43.0 \\
Yes & 65 & 57.0 \\
No & & \\
Close Contact History & 90 & 78.9 \\
Yes & 24 & 21.1 \\
\hline No & & \\
\hline
\end{tabular}

Based on the results of multivariate analysis (Table 3.), there are four remaining variables, namely gender, signs and symptoms, comorbidities, and close contacts. The results of the logistic regression test on the variables of gender, signs and symptoms, comorbidities, and history of close contact showed the $p$-value of each variable, namely $\mathrm{p}=0.001, \mathrm{p}=0.005, \mathrm{p}=0.001$, and $\mathrm{p}<0.001$ which stated that there was a significant relationship between gender, signs and symptoms, comorbidities, and close contact of respondents with the incidence of COVID-19 infection in the Slawi
Health Center work area. The Wald value of each variable is the sex of 10.73 , signs and symptoms of 7.92 , comorbidity of 11.50 , and close contacts of 13.71 (Table 3).

To see which determinant is the strongest or most dominant, it can be seen from the variable which has the smallest $\mathrm{p}$ value or the largest Wald value. Thus, it can be concluded that the determinant that has the strongest contribution to predict the incidence of COVID-19 infection in the working area of the Slawi Health Center is the close contact variable with $\mathrm{p}<0.001$ and Wald $=13.71$. 
Kholifah et al./ Risk Factors for COVID-19 Infection in Rural Areas

Table 2. Bivariate Analysis of Factors Related to The Incidence of COVID-19 Infection in Rural Areas

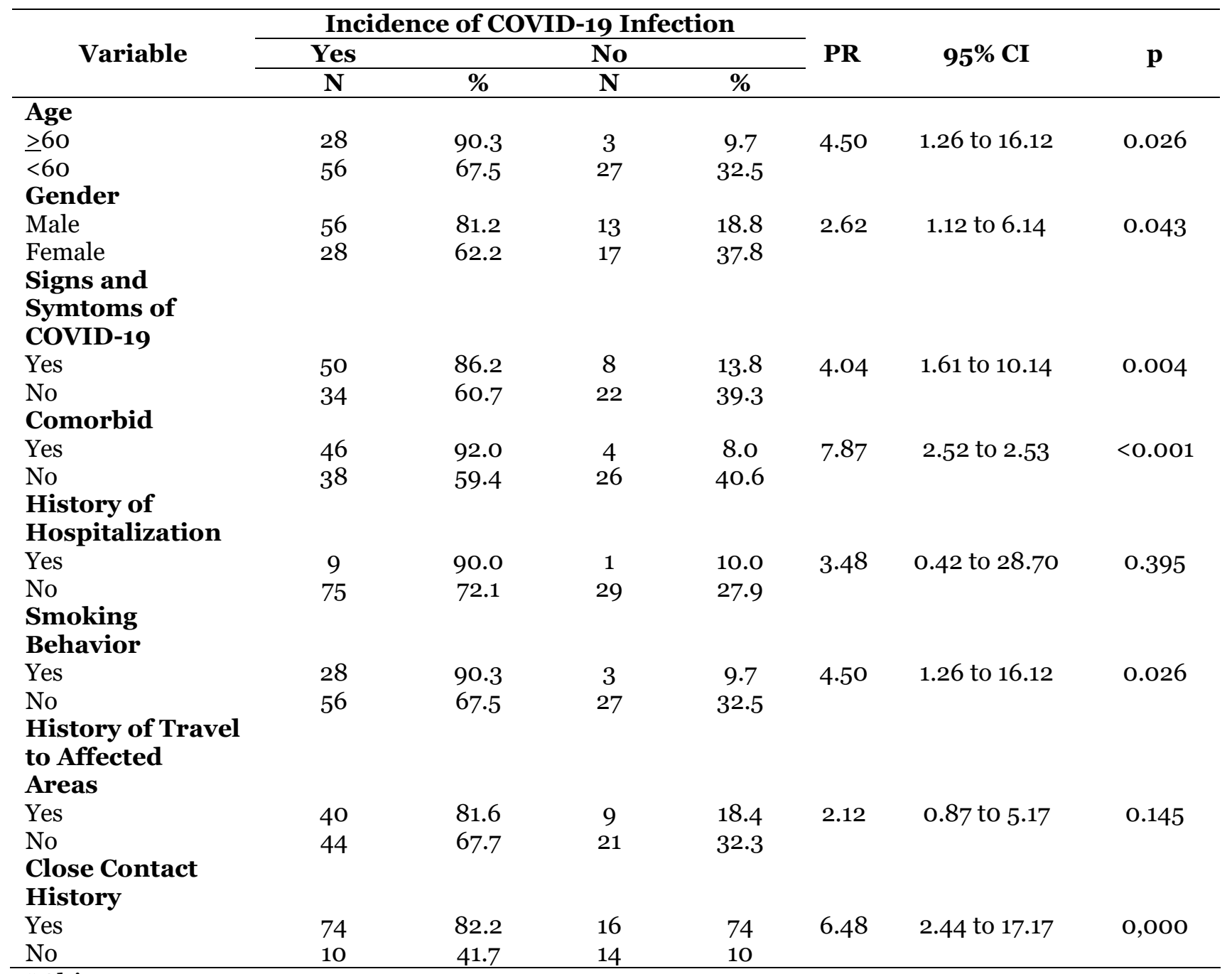

${ }^{*}$ Chi-square test

3. Multivariate analysis

Table 3. Multivariate Analysis of Factors Related to The Incidence of COVID-19 Infection in Rural Areas

\begin{tabular}{lccccc}
\hline \multicolumn{1}{c}{ Variable } & B & Wald & PR & 95\% CI & P \\
\hline Gender & 2.11 & 10.73 & 8.21 & 2.33 to 28,95 & 0.001 \\
Signs and Symptoms of COVID-19 & 1.82 & 7.92 & 6.161 & 1.74 to 21.85 & 0.005 \\
Comorbid & 2.46 & 11.50 & 11.76 & 2.83 to 48.83 & 0.001 \\
Close Contact History & 2.63 & 13.71 & 13.91 & 3.45 to 56.04 & 0.000 \\
\hline Constant & -3.58 & 14.72 & 0.03 & & $<0.001$ \\
\hline
\end{tabular}

*Logistic Regression Test

\section{DISCUSSION}

This study shows a significant relationship between age and the incidence of COVID-19 infection in the working area of the Slawi Health Center. This is in line with the research of Antezana et al., (Antezana et al.,
2020). who stated that age had a significant relationship with the incidence of COVID19 infection. Although the age category of the elderly is not uniform, some say that older people aged $>80$ years are at high risk of contracting the Corona Virus (accor- 
ding to Chinese researchers), elderly people aged $>50$ years (according to the Mayor of New York) and there are even Indonesian researchers who state people aged 45-65 vulnerable to exposure to the Corona Virus. This difference of opinion regarding the elderly age category is reasonable, considering that the disease caused by the Corona Virus is a new disease that is still being researched (Siagian, 2020). The elderly are included in the high-risk group for being infected with COVID-19 because of the degenerative process of anatomy and physiology in the elderly body, so they are susceptible to disease, decreased immunity, plus the elderly who suffer from comorbidities will cause their body condition to weaken making it easier to be infected with COVID-19 (Hidayani, 2020).

Gender in this study has a significant relationship with the incidence of COVID19 infection in the work area of the Slawi Health Center. And this is in line with the research of Wang, et al (Wang, Yin, et al., 2020), which revealed a significant relationship between gender and the incidence of COVID-19 infection. Women are more protected from COVID-19 than men because they have an $\mathrm{X}$ chromosome, and sex hormones like progesterone play an important role in innate and adaptive immunity. In addition, the habit of men who tend to leave the house more often causes men to be more susceptible to being infected with COVID-19 than women (Cen et al., 2020).

Based on statistical tests, it shows a significant relationship between signs and symptoms and the incidence of COVID-19 infection in the working area of the Slawi Health Center. According to research by Wang et al. (Wang et al., 2020), signs and symptoms are related to the incidence of COVID-19 infection. Signs and symptoms of significant COVID-19 infection are anorexia, shortness of breath, pharyngeal pain, and vertigo. In each country, in determining the criteria for signs and symptoms of COVID-19, it refers to the provisions of WHO. In Indonesia, guidelines for determining the symptoms of COVID-19, one of which refers to guidelines for the diagnosis and management of pneumonia and COVID-19, namely a person is said to be COVID-19 if he experiences three main symptoms of fever, dry cough (a small portion of phlegm) and difficulty breathing or shortness of breath (Direktorat Jendral Pencegahan dan Pengendalian Penyakit (P2P), 2020).

In addition, on other variables, it was found that there was a significant relationship between comorbidities and the incidence of COVID-19 infection in the working area of the Slawi Health Center. In most studies, it is stated that people with chronic diseases such as heart disease, diabetes, lungs are also a group at high risk of being infected with COVID-19. Research by Antezana et al (Antezana et al., 2020) stated that hypertension has a significant relationship with the incidence of COVID19 infection. Hypertension can increase the risk of morbidity and worsen the prognosis of COVID-19 due to the consumption of ACE inhibitors and ARBs as hypertension drug interventions (Tignanelli et al., 2020).

In the study of Cen et al (Cen et al., 2020) it was also stated that there was a significant relationship between diabetes mellitus and the incidence of COVID-19 infection. Patients with diabetes mellitus are more susceptible to COVID-19 infection due to hyperglycemia, impaired immune function, vascular complications and comorbidities such as hypertension, dyslipidemia, and cardiovascular disease (Roeroe et al., 2021).

Cardiovascular disease is also one of the comorbidities that support the 
occurrence of COVID-19 infection. According to Wang et al (Wang, $\mathrm{Hu}$, et al., 2020) in their research, stated that cardiovascular disease has a significant relationship with the incidence of COVID-19 infection. This is because people who suffer from cardiovascular disease will be given drugs that contain ACE 2 and ARBs that protect the lungs. Meanwhile, SARS-CoV2 uses the protein ACE 2 to enter cells. ACE 2 is a membrane protein that has a physiological function, namely lung protection, but is the entry point for viruses in the body that will cause cardiovascular toxicity (Driggin et al., 2020).

The study of Cumming, et al. (Jr et al., 2019) stated that Chronic Obstructive Pulmonary Disease (COPD) has a significant relationship to the incidence of COVID-19 infection. This is because COPD treatment will require ACE and ARB as physiological protection in the lungs. However, the drug will later trigger the entry of SARS-CoV2 or the coronavirus in the body so that the risk of being infected with COVID-19 will increase (Hidayani, 2020).

The proportion of respondents who were confirmed to have COVID-19 was more in the category without a history of hospitalization, which was $72.1 \%$. According to Hidayani (2020), in their research, it was revealed that at the Zhongnan Hospital, it was reported that patients who initially only had symptoms of abdominal pain were then treated at the same hospital as COVID-19 patients and eventually contracted COVID-19 patients. In this study, there was no significant relationship between a history of hospitalization and the incidence of COVID-19 infection. In contrast to the research of Wang, et al (Wang, $\mathrm{Hu}$, et al., 2020) which stated that a history of hospitalization had a significant relationship with the incidence of COVID19 infection.
The risk factor for smoking is also related to the incidence of COVID-19 infection in the work area of the Slawi Health Center. Smoking can make lung cells more susceptible to SARS-CoV2 disease by increasing its receptor, the ACE2 molecule (Siagian, 2020) And this is not in line with the research of Cen et al (Cen et al., 2020) which stated that there was no significant relationship between smoking behavior and the incidence of COVID-19 infection.

Meanwhile, travel history shows no relationship with the incidence of COVID19 infection in the working area of the Slawi Health Center. This is not in line with the CDC statement, which states that a history of traveling to infected areas increases the chance of contracting and spreading COVID-19 (CDC, 2020).

Then the proportion of respondents infected with COVID-19 was more in the category of having a history of close contact, $82.2 \%$. This study stated that a history of close contact had a significant relationship with the incidence of COVID19 infection in the work area of the Slawi Health Center. And this is in line with the CDC statement, which states that a history of close contact can increase the chance of contracting and spreading COVID-19 (CDC, 2020). Based on the results of this study, it can be concluded that age, gender, signs and symptoms, co-morbidities, smoking, and close contact can increase the incidence of COVID-19 infection in rural areas. The limitation of the research is recall bias, the forgetting factor of the respondents can cause this. Efforts were made to minimize recall bias in this study by conducting indepth interviews to obtain accurate and complete information.

\section{AUTHOR CONTRIBUTION}

Siti Putri Nur Kholifah, Mahalul Azam, and Muhamad Zakki Saefurrohim together for- 
mulate problem formulations, collect data, and analyze research results.

\section{FUNDING AND SPONSORSHIP}

This research is self-funded.

\section{ACKNOWLEDGEMENT}

The authors wish to thank the Departement of Public Health, Faculty of Sport Science, Universitas Negeri Semarang, for supporting of this working group. No financial support was received for this study.

\section{CONFLICT OF INTEREST}

There is no conflict of interest in this study.

\section{REFERENCE}

CDC (2020). Interim Guidance for Collection and Submission of Postmortem Specimens from Deceased Persons Under Investigation (PUI) for COVID19. February 2020.

Cen Y, Chen X, Shen Y, Zhang X-H, Lei Y, $\mathrm{Xu}$ C, Jiang W-R, et al. (2020). Risk factors for disease progression in patients with mild to moderate coronavirus disease 2019-a multi-centre observational study. Clin Microbiol Infect. 26(9): 1242-1247. doi: 10.1016/j.cmi.2020.05.041.

Dinas Kesehatan Provinsi Jawa Tengah. (2021). Tanggap COVID-19 Provinsi Jawa Tengah.

Direktorat Jendral Pencegahan dan Pengendalian Penyakit (P2P) (2020). Pedoman Pencegahan Dan Pengendalian Coronavirus Disease (COVID-19) (L. Aziza, A. Aqmarina, \& M. Ihsan (eds.)). Kementerian Kesehatan RI.

Driggin E, Madhavan MV, Bikdeli B, Chuich T, Laracy J, Biondi-Zoccai G, Brown TS, et al. (2020). Cardiovascular considerations for patients, health care workers, and health systems during the COVID-19 Pandemic.
J Am Coll Cardiol. 75(18): 2352-2371. doi: 10.1016/j.jacc.2020.03.031.

Epidemiology Working Group for NCIP Epidemic Response, Chinese Center for Disease Control and Prevention (2020). The epidemiological characteristics of an outbreak of 2019 novel coronavirus diseases (COVID-19) in China. Zhonghua Liu Xing Bing Xue Za Zhi. 41(2):145-151. doi: 10.376o/cma.j.issn.0254-6450.2020.02.003.

Escalera-Antezana J, Lizon-Ferrufino NF, Maldonado-Alanoca A, Alarcon-Dela-Vega G, Alvarado-Arnez LE, Balderrama-Saavedra MA, BonillaAldana, DK, et al. (2020). Risk factors for mortality in patients with Coronavirus Disease 2019 (COVID-19) in Bolivia: An analysis of the first 107 confirmed cases. Infez Med. 28(2): 238-242. https://pubmed.ncbi.nlm.nih.gov/32487789/.

Hastuti N, Djanah SN (2020). Literature Review Study: Transmission and Prevention of The Spread of COVID-19. Jurnal Kesehatan Masyarakat. 7(2): 70-76.

Hidayani WR (2020). Faktor Faktor Risiko Yang Berhubungan Dengan COVID 19: Literature Review. Jurnal Untuk Mayarakat Sehat (JUKMAS). 4(2): 120-134. doi: 10.52643/jukmas.v4i2.1015 .

Jr LJR, Simberkoff MS, Bessesen MT, Brown AC, Cummings DAT, Gaydos CA, Los JG, et al. (2019). N95 Respirators vs Medical Masks for Preventing Influenza Among Health Care Personnel: A Randomized Clinical Trial. JAMA. 322(9): 824-833. doi: 10.1001/jama.2019.11645.

Kementerian Kesehatan RI (2021). Statistical data of positive confirmed cases of COVID-19. https://covid19.go.id/. 
Kerbage A, Matta M, Haddad S, Daniel P, Tawk L, Gemayel S, Amine A, et al. (2021). Challenges facing COVID-19 in rural areas: An experience from Lebanon. Int J Disaster Risk Reduct. 53(2021): 102013. doi: 10.1016/j.ijdrr.2020.102013.

Liu X, Zhang D, Sun T, Li X, Zhang $\mathrm{H}$. (2020). Containing COVID-19 in rural and remote areas: experiences from China. J Travel Med. 27(3):taaao6o. doi: 10.1093/jtm/taaao6o.

Mueller JT, McConnell K, Burow PB, Pofahl $\mathrm{K}$, Merdjanoff AA, Farrell J (2021). Impacts of the COVID-19 pandemic on rural America. Proc Natl Acad Sci U S A. 118(1): 2019378118. https://doi.org/10.1073/pnas.2019378118.

Ranscombe P (2020). Rural areas at risk during COVID-19 pandemic. Lancet Infect Dis. 20(5): 545. doi: 10.1016/S1473-3099(20)30301-7.

Roeroe PAL, Sedli BP, Umboh O (2021). Faktor Risiko Terjadinya Coronavirus Disease 2019 (Covid-19) pada Penyandang Diabetes Melitus Tipe 2. ECliniC. 9(1): 154-160. doi: 10.3579o/ecl.9.1.2021.32301.

Siagian TH (2020). Mencari Kelompok Berisiko Tinggi Terinfeksi Virus Corona Dengan Discourse Network Analysis. Jurnal Kebijakan Kesehatan Indonesia. 9(2): 98-106. doi: 10.22146/jkki.55475.
Tegal District Health Office (2020). COVID-19 Case Data 2020.

Tignanelli CJ, Ingraham NE, Sparks MA, Reilkoff R, Bezdicek T, Benson B, Schacker T, et al. (2020). Antihypertensive drugs and risk of COVID19?. Lancet Respir Med. 8(5): 30-31. doi: 10.1016/S2213-2600(20)301533.

Wang D, Hu B, Hu C, Zhu F, Liu X, Zhang J, Wang B, et al. (2020). Clinical characteristics of 138 hospitalized patients with 2019 Novel Coronavirus-Infected Pneumonia in Wuhan, China. JAMA. 323(11): 1061-1069. doi: 10.1001/jama.2020.1585.

Wang D, Yin Y, Hu C, Liu X, Zhang X, Zhou S, Jian M, et al. (2020). Clinical course and outcome of 107 patients infected with the novel coronavirus, SARS-CoV-2, discharged from two hospitals in Wuhan, China. Crit Care. 24(1): 188. doi: 10.1186/s13054-02002895-6.

WHO (2020). Global surveillance for COVID-19 disease caused by human infection with the 2019 novel coronavirus. https://apps.who.int/iris/handle/10665/331231. 